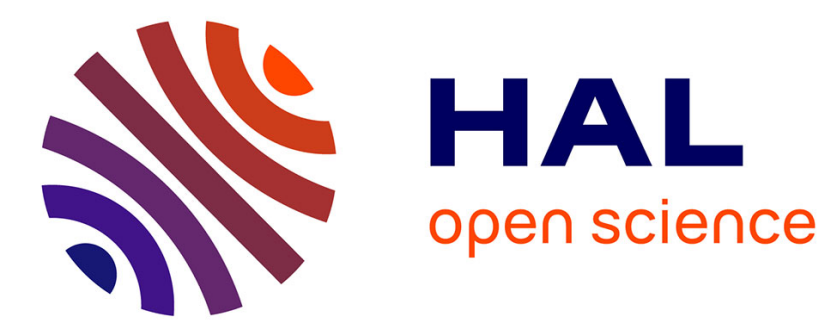

\title{
Education in Sustainable Development: How Can Science Education Contribute to the Vulnerability Perception?
}

Jean-Marc Lange

\section{To cite this version:}

Jean-Marc Lange. Education in Sustainable Development: How Can Science Education Contribute to the Vulnerability Perception?. Research in Science Education, 2012, 42 (1), pp.109 - 127. 10.1007/s11165-011-9259-9 . hal-01690493

\section{HAL Id: hal-01690493 \\ https://hal.umontpellier.fr/hal-01690493}

Submitted on 28 Jan 2018

HAL is a multi-disciplinary open access archive for the deposit and dissemination of scientific research documents, whether they are published or not. The documents may come from teaching and research institutions in France or abroad, or from public or private research centers.
L'archive ouverte pluridisciplinaire HAL, est destinée au dépôt et à la diffusion de documents scientifiques de niveau recherche, publiés ou non, émanant des établissements d'enseignement et de recherche français ou étrangers, des laboratoires publics ou privés. 
Res Sci Educ (2012) 42:109-127 DOI 10.1007/s11165-011-9259-9

\title{
Education in sustainable development: how can science education contribute to the vulnerability perception?
}

\author{
Dr. JM Lange, UMR STEF, ENS Cachan/INRP; \\ And \\ IUFM de Haute Normandie \\ University of Rouen \\ 2 rue du tronquet \\ 76130 Mont Saint Aignan \\ France \\ Jean-marc.lange@univ-rouen.fr
}

\begin{abstract}
Education for human development within the constraints of sustainability is problematic for schools. On one hand, it is a political idea that continues to evolve with successive compromises between social groups with differing or even conflicting interests. ESD is therefore inherently 'non-disciplinary' and cannot be the basis of a single school subject if we wish to keep the creativity that results from the dynamics at work.

On the other hand, SD leads us to think collectively about solutions that ensure a future of our choosing that preserves the biological capacity of the planet and to reduce our vulnerability. The sciences thus have a key role: their ability to question the world and to model the consequences of collective and individual choices. But there is a risk of technocratic drift and SD leads us to think about society's values and aims. A new link is established between sciences and humanities with a democratic model in sight.

This paper presents what is possible out of the prospective scenarios method within general and compulsory education by seeking, through an empirical approach, to determine its feasibility, its contributions, its limits, and to locate the place of science education in the elaboration of the perception of "vulnerability". Both primary and secondary schools are concerned.
\end{abstract}

\section{Key words}

Education for sustainable development - Vulnerability - Risk - Science education - Primary and secondary school

\section{Introduction}

Sustainable Development (SD) can be understood as a deep and irreversible process of expansion of the scope of the policy to the whole planet, including in its physical and biological dimensions. This change, driven by international institutions such as the UN as well as NGOs, creates a renewed need for knowledge. The resulting demand brings about a profound rethinking in national academic research. One consequence is that major research institutions have become part of an SD strategy to which each must respond, while bringing about significant changes in both goals and research methods (O. Godard, 2001). The idea of SD is gradually gaining credibility in the scientific world while continuing to be debated in society more broadly. It plays a role in mobilising social actors in general and researchers in particular, and calls for their responsibility. 
This enlargement of the policy's scope can mainly be seen through a new concern given to future consequences of human actions. Born in Germany about thirty years ago, a principle of anticipation, and then foresight (Vorsorgeprinzip) vis-à-vis the management of natural resources, was developed by the German government at the time. This principle seeks to go beyond mere protection against immediate dangers, and is envisaged most often according to an insurance approach, for a consideration of the long-term risks, whether or not identified, and the environmental and social implications of the decisions taken (Doron, 2009). It was incorporated by international and national authorities into the term 'precautionary principle'. This principle became constitutional in France in 2004.

The current development of human societies is therefore called into question under the new constraint of sustainability. Consideration of the short, medium or long term future is needed to meet this requirement of sustainability. The importance of this has been the subject of much debate. However, it is more through the concept of vulnerability that sustainability gives rise to thinking and research, 'vulnerability' of social groups and/or bio-physical systems. For Bidou and Droy (2009) vulnerability can be understood to be:

'The characteristics and situation of a person or group that influence their abilities to anticipate, cope, resist and recover after the impact of a hazard.'

A component of risk, the concept of vulnerability includes the concept of 'anticipation' of the implications of decisions made and suggests actions to reduce it. It is in this way inherently 'hybrid' (Jollivet, 2009). Consistent with this view of vulnerability, the current research on development employs an interdisciplinary methodology to analyse situations in terms of root causes, dynamic pressures and dangerous conditions, characterising vulnerability in view of a hazard (Wisner et al, 2003). In education situations, especially in the case of general and compulsory education, we will retain, initially, the need for a perception and ownership of the vulnerabilities of our societies by the pupils themselves. This means their ability to identify risks and issues at stake, to anticipate the implications of their actions, and to identify current mechanisms for efforts to reduce vulnerabilities.

\section{Key questions}

We have proposed (Lange and Martinand, 2010) a familiarisation of prospective scenario approaches in school. The prospective scenarios aim to establish the advantages and disadvantages of solutions and strategies used and allow the streamlining, on the lowest possible level, of a procedure of choice between options (Mermet, 2003). They thus help to reduce uncertainties and to think about the future. In this perspective, support from the sciences proves necessary. This idea of science and technology education working towards the understanding the problems of society is part of what Roberts (2007) calls 'Vision II'. But in what form can the contribution be envisaged? Does the sole 'intelligibility' of SD issues through the use of the sciences turn out to be enough? Do we not risk again coming across a technocratic drift long emphasised by authors such as Fourez (1994)? For him, inspired by Boltanski and Thévenot, technocracy purports to show constraints which will be treated 'as a determination acting on individuals without demanding an intervention of their will'.

Our aim is to develop what is possible of the prospective scenarios method within general and 
compulsory education by seeking, through an empirical approach, to determine its feasibility, its contributions, its limits, and to locate the place of science education in this system.

\section{Methodology \\ Empirical support}

To answer these questions, three projects were monitored, in upper primary school, lower secondary school and upper secondary school. The teachers involved, integrated into the research group operating according to the methods of collaborative research (Bednarz et al, 2001), had in their roadmap the recommendation to include in their project an element of anticipation, if possible in the form of prospective scenarios. This is not a matter of building an ideal type or developing a comprehensive picture of what exists, but exploring the possible ways of bringing a new educational reality into existence. The methodology used is that of the case study.

\section{Project 1: primary school}

The project carried out at upper primary level is aimed at science, technology and citizenship education. The aim was to construct a model giving an account of what an ESD project could be, shaped by the various opinions expressed on the issue. The pupils elected children to play the role of delegates and outlined the proposal, made by elected local officials, to study two projects of the school: the relevance of a rain water recuperation system (first year), and relevance of a solar water heater at the school (second year). Pupils set out the problems to solve to meet this requirement. Having checked the feasibility of the project, modelling was done.

The key elements of the project (first year) are recounted below:

- initial ownership of issues for the project in the form of in situ measurement of the biotic index of a river, in order to build the idea of pollution;

- use of some biological models (ecosystem, food webs, water cycle...);

- the achievement of mock-ups and technological models in order to verify the feasibility of the proposals of the rainwater harvesting;

- the solicitation of different partners (local water agency, director of a station of purification, architect, elected) ;

- structuring in the form of panels supported by an argued case and a presentation to the city council through the council of children

Then, the economic and environmental dimensions involved were explored, and a rationale was constructed over the course of the year in order to assess the advantages and disadvantages. Specific work was then carried out on the rationale. A final debate made it possible for them to put selected arguments to the test in the presence of experts and then in front of local "decision makers". The work to develop scenarios, however, was integrated only at the end of the project.

Project 2: middle school

Carried out in lower secondary school as a cross-subject project (Life and Earth Science (LES) and technology), the project aimed ultimately to form the basis for obtaining the label '3D establishment' (establishment in a way of sustainable development). This cross-subject project enabled computerised slide shows to be developed, focusing on the development of prospective scenarios, on the issue of waste and how to manage and reduce it. It took the form of the construction of prototype containers and included a feasibility study, establishment of functional specifications, selection and validation of the prototype, then the creation of manufacturing lines. In addition, many discussions have allowed exchange on these issues. On balance, the debate argued for implementation of a unifying project: "Think Global, Act Local". This involved 
considering a range of opinions in relation to scientific rationality from modelling to develop its own knowledge. It is then proposed the achievement of panels of information, awareness-raising for the entire college (acting locally). In the end, (first year) the students have created original models of wheelie bins for the collection of recyclable paper and containers for batteries and printer cartridges. Each year, a new project was completed.

\section{Project 3: High School}

Carried out in the third from last year of secondary school, this project was integrated into the Life and Earth science (LES) class, together with history, geography and mathematics classes, and concerned Climate Change. Entry into the sequence is from the societal dimension.

A discussion of about 30 minutes with students identified the need to formulate an argument constructed to legitimize the proposals. This argument, in the event scientific, is to proceed by responding to the cognitive impasses encountered by the students. A literature search on the Internet allows searching for evidence while at the same time querying on the latter: their scientific character, their objectivity and relevance. This research is also the opportunity to be confronted with forms of various communications used by scientists: photography, graph, table... The project conducted is multidisciplinary:

- a History-geography / LES collaboration. This collaboration is the first to have been conducted. Climate change and its consequences allow weather considerations to address the concept of risk, combination of a hazard and vulnerability, and history/geography background. The risk of cyclones may as well be addressed in the extension of this study of climate change, with in particular, the consequences on the more populated areas.

- a Physical-chemistry / LES collaboration. This case involves the teaching of physics/chemistry to treat luminous radiation, and associated emission and the absorption matters. The understanding of the processes at work in the greenhouse effect under control, the latter, in LES, can then be processed more quickly.

- a Mathematics / LES collaboration. This collaboration resulted in the development of knowledge relating to the descriptive statistics for the program. The data relating to climate change: rates of carbon dioxide, annual mean temperatures, and annual number of cyclones actually allow a mathematical treatment. A treatment that leads to the obtaining of graphic representations viewing in a more or less expressive the changes to the implementation and can enable a critical analysis of the choice of scientific representations.

Meetings were held with experts and a final presentation to the families was made at an open day. The approach focuses on scientific modelling and simulations and includes elements of debate.

\section{Empirical methods}

Two methods are used:

On one hand, the method is one of highlighting the global dynamics at work among pupils. Indeed, the idea of SD and that of ESD - not as a solution but as a collective process of seeking solutions - leads us to give an account of the dynamics at work among pupils rather than a level to be achieved. To do this, the interviews of participating pupils are analysed using a grid developed by theoretical and empirical trial and error during a pre-exploratory phase. This grid, which can be found in the appendix (Lange and al, 2008) includes the level of complexity of speech, the ownership of the issues at stake in SD and ESD and the propensity to act, which allows for the establishment of support for collective action and identification of the obstacles hindering or counteracting such action. Interviews were conducted at the start and the end of this 
process.

On the other hand, in this paper there is also a special focus on the assimilation/integration of the issues at stake, the perception of vulnerability and the otherness to an individual or collective action.

[NEEDS A SENTENCE OR TWO ON DISCOURSE/GRAMMATICAL ANALYSIS TO INTRODUCE THIS APPROACH] Ownership of the issues at stake in sustainability is assessed by counting at the start and at the end the instances of je ('I') or on (understood in the collective sense of 'we' and usually followed by an action verb) in relation to the instances of impersonal on - understood in a generic sense and usually followed by a conditional (Lange and al., 2008, 2010).

The perception of vulnerability is identified through the expression in pupils' speech of a feeling of indifference or rejection of sustainability issues, the postponement of the plan to act until later (future generations), or the expression of urgency to act now for a future we can better master (Lange and al., 2008, 2010).

Finally, there is the issue of otherness: the other is expressed as a support for or an obstacle to the action for SD, because of the need to take collective responsibility for issues of sustainability (Lange and al., 2008, 2010).

\section{Data collection}

The projects' highlights were filmed, and the pupils were interviewed on a voluntary basis at all stages of the projects. The technique is that of semi-structured interviews and follows a framework guide adapted to the class level and time of data collection.

The interviews are carried out in groups at primary level, and individually at secondary level. Only partial results on the first semester of 2008 are presented in this paper. They were attained at the start and end of the semester, as part of the ongoing educational projects:

\begin{tabular}{|l|l|l|l|}
\hline Project & $\begin{array}{l}\text { Number } \\
\text { interviews at the } \\
\text { start }\end{array}$ & $\begin{array}{l}\text { Number } \\
\text { interviews at the } \\
\text { end }\end{array}$ & Methods \\
\hline $\begin{array}{l}\text { Upper primary the pupils in the } \\
\text { level }\end{array}$ & $\begin{array}{l}\text { All the pupils in the } \\
\text { class }\end{array}$ & Interviews in pairs \\
\hline $\begin{array}{l}\text { Lower secondary } \\
\text { level, cross-subject } \\
\text { project }\end{array}$ & 10 & 10 & $\begin{array}{l}\text { Semi-structured } \\
\text { interviews on a } \\
\text { voluntary basis } \\
\text { conducted in parallel } \\
\text { with regular class } \\
\text { tuition. }\end{array}$ \\
\hline $\begin{array}{l}\text { Upper secondary } \\
\text { level, Life and } \\
\text { Earth Science }\end{array}$ & 16 & & \\
\hline
\end{tabular}

\section{Results}

\section{Educational dynamics}

\section{Project 1}

As the interviews were carried out in groups, it was not possible to analyse individual dynamics. 
However, after the initial project was completed, a collective summary of what were thought to be the issues at stake was made in the form of posters, reproduced below:

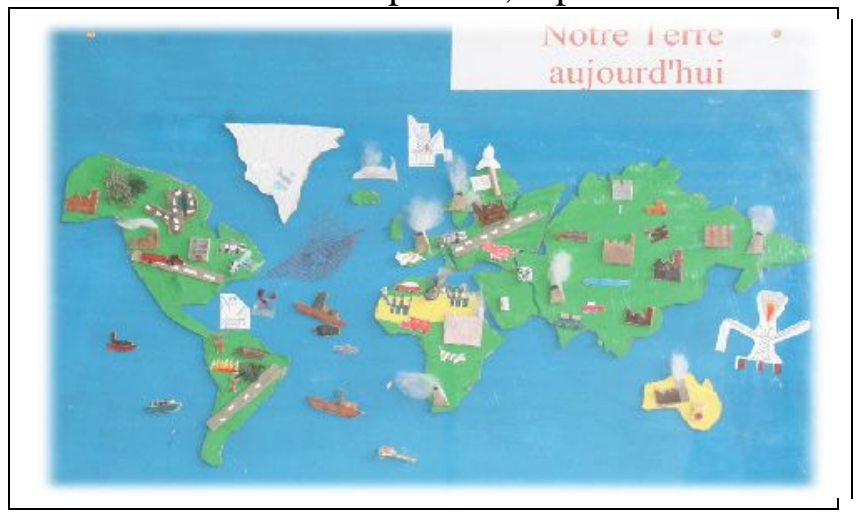

\section{Current world}

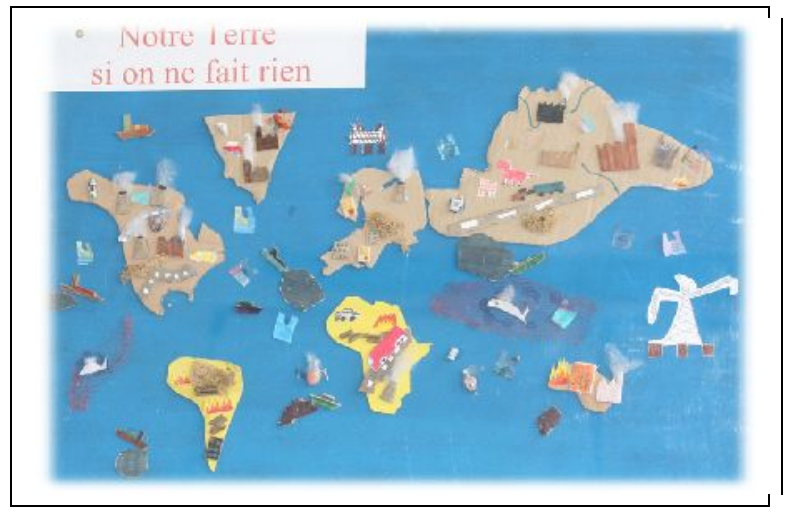

Catastrophism

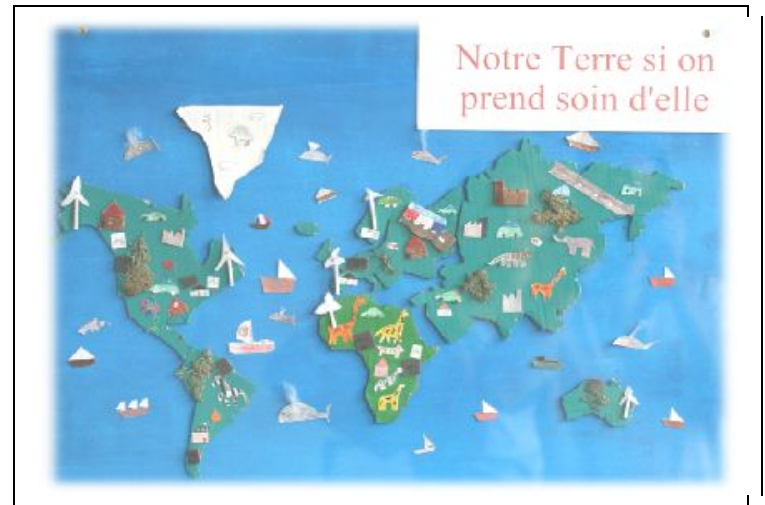

Ideal future

Figure 1: Posters produced by the pupils of project 1 (primary school)

\section{* Project 2}

Table 1: Dynamics at work in the pupils (Middle school)

\begin{tabular}{|l|l|l|}
\hline Pupils & $\begin{array}{l}\text { Change \& Synthesis } \\
\text { (Construction of a reasoned opinion, propensity to act, support for the new academic format) }\end{array}$ \\
\hline RSy & ++ & Increase in complexity of discourse ; Suitability of SD stakes, \\
\hline REm & + & Increase in complexity of discourse ; Propensity to act but the knowledge remains school \\
\hline RAlic & ++ & Destabilised by the new academic format; Increase in complexity of discourse \\
\hline RAlin & + & Desire to make good practices for others but not in acting it; Knowledge remains academic \\
\hline RNa & + & Positive evolution and weakness of the rational \\
\hline RD & + & Remain very "learned knowledge"; weakness of the rational \\
\hline RO & - & Regressive development; SD rejected (too difficult) \\
\hline RL & + & Increase in complexity of discourse ; Propensity to act; Others as a social constraint \\
\hline RCa & + & Propensity to act ; Increase in complexity of discourse; Others as a social constraint \\
\hline
\end{tabular}


NB: + notify a positive change; = notify an unchanging state; - notify a regression

\section{Project 3}

Table 2: Dynamics at work in the pupils (High school)

\begin{tabular}{|l|l|l|}
\hline Pupils & \multicolumn{2}{l|}{$\begin{array}{l}\text { Change \& Synthesis } \\
\text { (Construction of a reasoned opinion, propensity to act, support for the new academic format) }\end{array}$} \\
\hline RJU & + & Increase in complexity of discourse; Suitability of SD stakes; Convinced but not yet responsible \\
\hline RY & + & Increase in complexity of discourse; Suitability of SD stakes; Convinced but not yet responsible \\
\hline RLAE & + & Become aware; Desire to act but epistemic fatalism connected to the gravity of the situation \\
\hline RN & $=$ & Argued engagement; Lack of understanding of the scholar stakes of the ESD \\
\hline RMA & - & $\begin{array}{l}\text { Desire to act but content does not answer its desire; He is in action but doesn't waiting for } \\
\text { knowledge }\end{array}$ \\
\hline RH & ++ & Evolution towards discourse argued in relation to the appropriation of the stakes \\
\hline RJ & + & Discourse agreed upon towards a discourse superficial; Argumentative profit \\
\hline RS & + & $\begin{array}{l}\text { Too much young person to act; Discover political and economic analysis; He becomes convinced } \\
\text { but not yet responsible }\end{array}$ \\
\hline RG & + & In epistemic doubt at the beginning then becomes enough convinced but no yet involved as citizen \\
\hline RLAU & ++ & ; Suitability of SD stakes; Increase in complexity of discourse; Desire to act \\
\hline RMEG & + & Suitability of SD stakes ; Increase in complexity of discourse; Desire of action \\
\hline RCC & $=$ & Desire to act; Increase in complexity of discourse; Responsibility with intergeneration \\
\hline RCD & + & Beginning of suitability of SD stakes; Change in representation of science \\
\hline RCEL & - & Discourse remains superficial; Appreciate the debate, but indifferent about SD \\
\hline RMEL & + & $\begin{array}{l}\text { Convinced, indeed even responsible, but there is a drop of enthusiasm due to the new academic } \\
\text { format; Increase in complexity of discourse }\end{array}$ \\
\hline RCL & + & $\begin{array}{l}\text { Evolutions towards issue about SD, but not yet responsible. destabilised by the new academic } \\
\text { format (the academic format drive by the process and not by the product) }\end{array}$ \\
\hline
\end{tabular}

\section{Focusing}

Focusing on the assimilation/integration of the issues at stake; the perception of vulnerability and the otherness to an individual or collective action are made in this section.

\section{* Assimilation of the issues at stake}

The evaluation of an assimilation/integration of issue at stake is conducted through a quantitative approach. The graph below shows the evolution of the instances of $j e$ ('I') and on (understood to mean 'we') compared with the instances of on (understood in its generic sense).

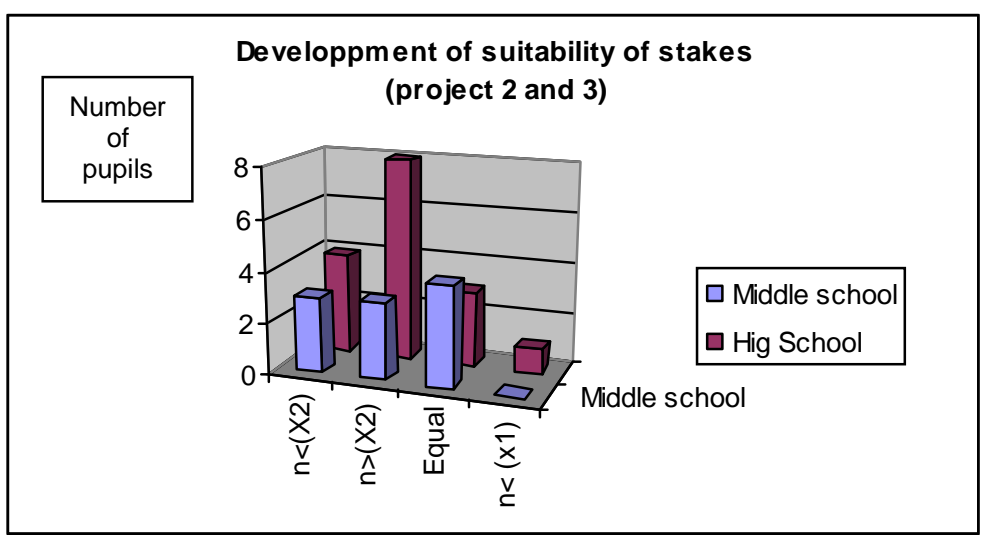




\section{- Perception of vulnerability}

The issue of time is an integral part of the issue of SD. However the planned action may be postponed to the distant future or, on the contrary, there may be an awareness of the need to act today for a future we can control.

\begin{tabular}{|l|l|}
\hline linguistic indicators & Extract of interviews \\
\hline Later & $\begin{array}{l}\text { "well we won't be able to breathe any more and if there } \\
\text { are children just after it'll be difficult for them to live in } \\
\text { that world' } \\
\text { 'It's so that when we have children, they won't be ill' }\end{array}$ \\
\hline Actual and urgent & $\begin{array}{l}\text { 'It's for all time, for now and for later' } \\
\text { "10 years from now if we keep on throwing rubbish } \\
\text { away the earth will die" }\end{array}$ \\
\hline
\end{tabular}
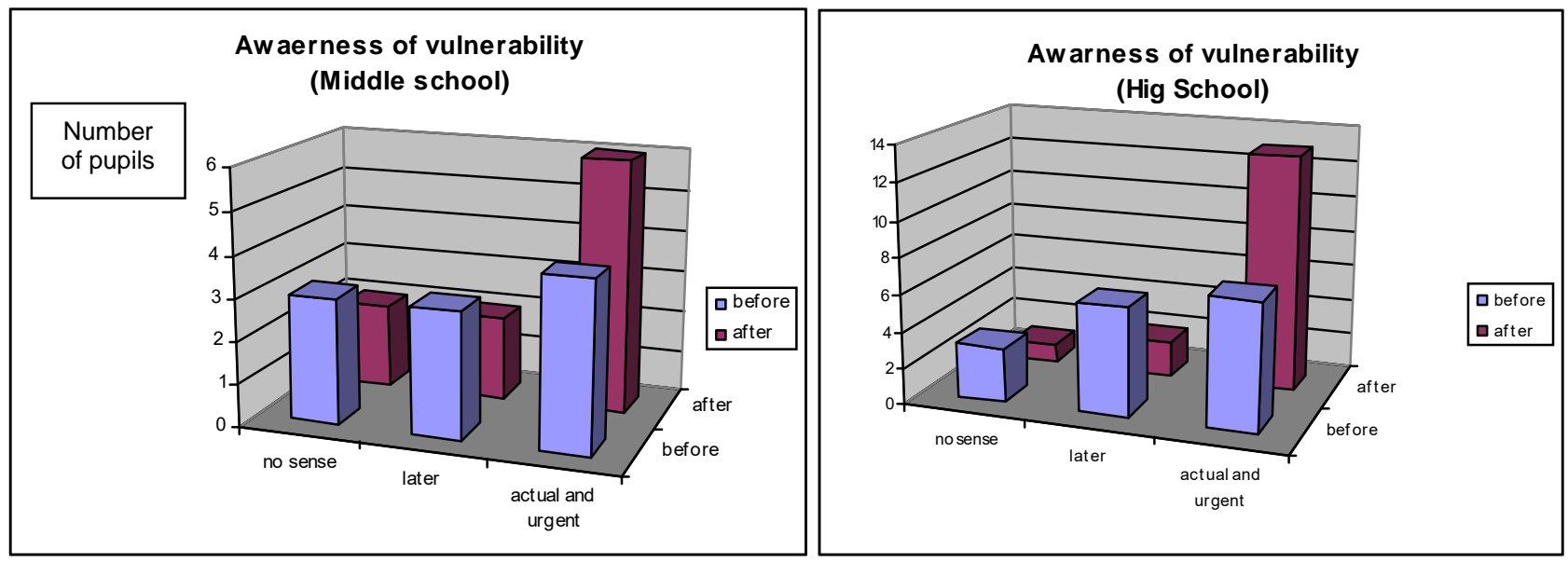

\section{Relationship to the other}

\begin{tabular}{|l|l|}
\hline Linguistic indicators & Extract of interviews \\
\hline $\begin{array}{l}\text { Positive ("other" like a } \\
\text { support) }\end{array}$ & $\begin{array}{l}\text { 'Well yes if everyone does it, it could maybe change a } \\
\text { bit...well, not totally" }\end{array}$ \\
\hline $\begin{array}{l}\text { Obstacle ("other" like } \\
\text { an difficulty) }\end{array}$ & "They're not interested" \\
\hline
\end{tabular}
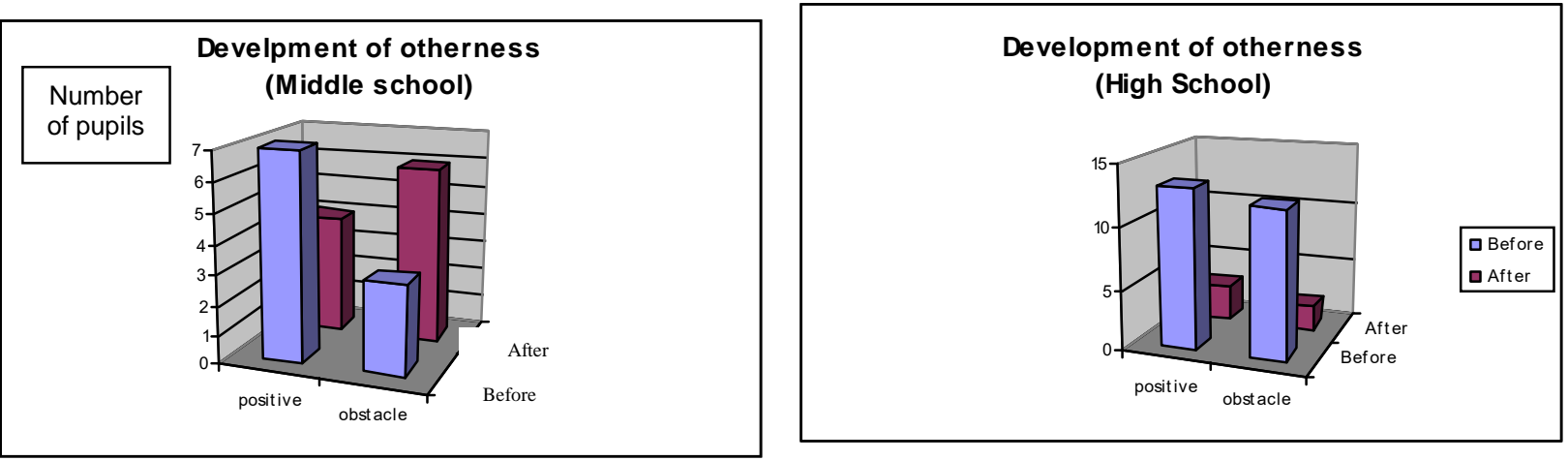


\section{Analysis of the results and discussion}

Obtained results are analysed from two points of view: that of their efficiency on pupils (about the three focuses) and that of the dynamics at work in the pupils.

\section{Project relevance and limitations}

The first project (primary school) aims to renew the dynamic of the science and technology class: the issue of the meaning of these teachings is settled by seeking an ability to understand social issues through an effective and active implementation, supplemented by an experience of participatory citizenship. This project could be a demonstration of Roberts' 'Vision II'. However, we can note that the ownership of the issues at stake in SD and the perception of vulnerability are made in simplistically dualist thinking: utopia or future catastrophe.

The second project (middle school), meanwhile, focuses directly on the development of prospective scenarios aiming to formulate problems about the issue of waste management, and then the technical implementation. No pupils refer to scenarios spontaneously in interview, except in the slideshow format in which the scenarios were developed and communicated to others: only the academic aspect of learning technology counts. However, the ownership of the issues at stake isn't evolving positively and a certain dynamic of perception is taking shape. Finally, the ability to interact with the other isn't reinforced.

The third project (high school) combines societal debates and an anchoring in the sciences. In particular, the use of scientific modelling and especially in their predictive function is systematic. The perception of vulnerability increases even more but a dynamic of ownership of the issues at stake does not appear. However, the project refers only to a purely individual responsibility: no effective and collective action is established outside the simple final presentation. This is reflected in the relationship with the other, which remains unchanged.

\section{Dynamics of change, effectiveness of activity}

For the pupils, the analysis is conducted from the perspective of the difficulties met and the dynamics of change at work in them, not in terms of a state to be achieved.

- Interview T0

MA0: 'Soon even we won't be able to live because it's creating a big problem which means that soon life... You can't be one to save the planet, everyone has to get involved'

- Interview T1

MA1: 'It's not too late, we can do something to save our planet, and there are solutions... (I'll) be able to talk to other people in my family so that they'll do it to and that's how it'll work'

- Interview T0

MEG0: 'I think it (the climate problem) is actually one for future generations... (Acting individually) isn't enough; I think it can provide a good basis'

- Interview T1

MEG1: 'We can reduce our consumption... it's down to us to act at any rate... to improve it everyone has to get involved... we are there for something at any rate, if everyone were to live like us the planet would really be ruined'

- Interview T0

CL0: '(The consequences of global warming) could be a total warming, so there'd no longer be men on Earth... I 
think in a very long time... We aren't scientists, I don't think we can do anything... (this class) is for culture, I don't think it's going to change me...'

- Interview T1

CL1: 'It taught me to pay attention to $\mathrm{CO}_{2} \ldots$ I wonder in my mind how it'll be in the future... we don't know exactly what's going to happen... I don't know what they (scientists) alone can do; it's all of us who can (do something)... everyone has to do something'

- Interview T0

LAE0: 'One person won't change anything...'

- Interview T1:

LAE1: '... if everyone got involved, maybe, just maybe, but maybe it's already too late! ... I realized that without meaning to I do something for the planet'

These dynamics are positive if the pupil progresses towards an ownership of the issues at stake, a more complex way of thinking, a renewed connection between science and society, a propensity to act today, and support for this education within the school.

They may be neutral if, for these characteristics, the pupil keeps his or her initial stance, particularly a 'utilitarian' stance, i.e. a relationship to the school only as a means of gaining a qualification.

Finally, we will describe them as negative if the pupil is progressively abandoning any intention and willingness to participate and act. We analyse this 'regressive' development in terms of epistemic inhibitions (a catastrophist relationship to the world) and social inhibitions (the other seen as an obstacle) respectively. There are two pupils in this situation in the High School. One of them shows indifference towards the issue of SD (CEL in Table 2) and the other has an attitude of rejection: eager to act, the pupil does not support the work carried out, mainly for reasons of lack of evidence (MA in table 2):

MATI: 'I don't think we've seen enough concrete acts, we saw the reason but not enough concrete acts'.

\section{General Discussion}

It seems that a number of generalisations can be drawn from our results from these three case studies, because they were found to be relatively stable over the duration of the research. These regularities relate to the following points:

\section{Catastrophist effect and thinking}

It is possible to envisage two levels of interpretation of catastrophism. A first level corresponds to an emotional connection and struggle with the world that originates from intrinsic mechanisms inherent in the psychological development of the learners and extrinsic and collective mechanisms relayed by the media. Research in science education has long identified the first mechanism by using science history and highlighted its function as an 'epistemological obstacle' which would then be overcome. But there is another level of catastrophism that Dupuy (2002) calls 'enlightened catastrophism'. This underlines the fact that belief in the possibility that catastrophes occur is a necessary and indispensable condition to acquire the conviction that there is a need to act and change the status quo. He argues that this state of conviction can be achieved through backing by scientific knowledge. He claims the creative capacity of humans generates the necessary changes for a progression to an ethic of responsibility, thus returning to the conviction/responsibility distinction developed by Weber (1959). 
In the pupils' speech we often find, especially among the youngest, this first level of catastrophism which effectively translates into a feeling of helplessness and suppression of the intention to act. This is expressed in an epistemic register: 'it's too serious, there's nothing to be done any more' but also in a register of otherness that reinforces it: 'I alone can't do anything; everyone should be getting involved'. This can be found in the pupils' speech initially or instead develop as the educational action is taking place. We are therefore keen to put forward the theory that the enactment of effective and collectively agreed solutions is necessary for the pupils to avoid or overcome this state of inhibition. This is an issue of paramount importance for ESD.

Pupils could take ownership of the prospective scenarios approach in two distinct and contrasted forms:

- a discursive form, possibly but temporarily catastrophist, corresponding to an initial ownership of the issues at stake and the process to formulate problems and to conceptualize narratives, that different studies have established about science education (Orange, 2007). This common narrative that's appearing also promotes a new worldwide "live-together" perspective (Descola, 2011).

- an elaborate form that involves scientific concepts and modelling, we are calling "reasoned opinion" (Lange and Victor, 2006).

\section{Ownership of spatiotemporal and complexity scales}

For the youngest pupils, it is clear that scalar and complexity thinking is, as confirmed by several interviews: 'If I don't do it [collecting rainwater], the planet will die'. This type of reasoning is also found in the higher levels. The aphorism 'act locally, think globally' often put forward as part of SD finds its limit here: the correct perception of the issues at stake and the possibility of the action are conditional on the ability to make connections in terms of quantified and prioritised importance. The gap in the question may be filled by multidisciplinary and literature-based investigations around issues at stake to work systematically on the spatiotemporal and complexity dimensions by mobilising the methods and concepts of various disciplines. 'Islands of rationality' like a result of a modality of interdisciplinary inquiry (Fourez; 1997; Bader and Therriault, 2008) on the issues would be developed.

\section{Importance and limits of the contribution of sciences}

We also bore in mind the irreversible trend towards explicit modelling in material and life sciences and in their teaching (Lange, 2005; Martinand, 2002). Modelling is not always explicative and it can then perform functions of prediction, decision support, assistance in understanding and therefore in conceptualisation and problematisation (representation, clarification, deduction or argumentation), overcoming obstacles (discontinuity, variability, etc.). All are critical functions for exploring consequences, conditions and opportunities for sustainable development.

\section{Vulnerability and risk}

Science education has rarely insisted on the fact that sciences do not produce certainty. As is stressed by Christensen (2009):

"School sciences, however, has rarely acknowledged the uncertain dimensions of science and there now seem to be important consequences of failing to do so. It is in relation to decision making where scientific knowledge is uncertain that risk understanding can make a significant 


\section{contribution."}

Precisely because there is uncertainty, sciences should place importance in their ability to reduce the uncertainty in determining the causes, and in suggesting rational methods of risk assessment by assigning them a probability necessary for the "decisions makers" to take action. But we must also recognize the uncertain nature of "doing" science and anchor it into society by giving science the place it deserves in the debates related to socio-scientific issues. Jenkins (2000) emphasizes the need to bridge the gap between a societal development of ever more uncertain and complex nature and a scientific education aimed more often at the development a belief in the power of science, which is a scientistic achievement. The challenge to science education is considerable and the question of the risk is the opportunity.

Science has long contributed to the determination of risks, but this view of the risk/vulnerability relationship has evolved considerably in recent years (Magnan, 2009). In the 1950s, risk was addressed in the form of a 'physical paradigm': the hard sciences (geology, etc.) dominated the work. Then in the 1980s, a second school of thought was organised around a 'structural paradigm': risk becomes an encounter between a hazard and vulnerability, and social sciences become more important. But they remain different approaches and ways of thinking in terms of complementarity with the hard sciences. This approach ultimately proved insufficient to explain differences in vulnerability between human groups. In the 2000s, a new paradigm, that of 'reciprocity' between hazard and vulnerability, leads to a dynamic, evolving vision of the relationship between humans and their environment and therefore risk, vulnerability and disruption, anchored in a given territory. The triple dimension of disruption/land/vulnerability replaces the traditional hazard/vulnerability approach and science can only enlighten the alea and the notification of a probability to the risk. It calls for complex approaches in which universal sciences and humanities and social sciences must learn to diversify in their focus and approach.

It is now recognized that two registers of risk perception come face to face: a scientific perception, most often expressed in terms of probability; and a social perception, often qualified of "irrational", dependent on the territorial affiliation and the feeling of vulnerability of the risk. These two registers define the acceptability of risk (Faucheux and Nicolai, 2005). However, little work is taking into account these two registers and the diverse approaches being called upon (Deram, Hayet and Van Staevel, 2006). Thus, Chevassus-au-Louis (2000, 2007) specifies this important distinction: the "experts" idea of risk is grounded in scientific rationality and defined in a quantitative and probabilistic manner. Another is the assessment of risk by citizens: the latter, considering the risk according to a "secular rationality", should not be confused with irrationality, according to qualitative criteria. There is a potential conflict of rationality that may be resolved appropriately by means of the democratic debate and of the precautionary principle. 




Figure 2 : vulnerability and science contribution

Sciences can only contribute very partially to citizens' appropriation of the vulnerability. Education in SD must therefore mobilize scientific education and humanities, and prepare the actors for democratic deliberation within particular contexts.

\section{Prediction and prospection}

We should make a clear distinction between prediction and prospection. The prediction function of scientific models is a product of a process of extrapolation based on a particular model. However, it is often found in the gap between prediction and fulfilment that there is room for scientific problematisation/conceptualisation. The models however make it possible to identify some unsuspected issues at stake, the parameters and their importance. This determination leads to a determination of the mechanisms for action.

Prospection meanwhile aims to determine possibilities in the form of scenarios developed on the basis of the available data. It is based on a complex analysis of the status quo and involves various models from different disciplines, including humanities and social sciences, without being limited to one of them (Mermet, 2003). It is therefore a process of supporting decisionmaking. If it is based on scientifically established data, it suggests decision-making procedures that transcend the science: prospection uses qualitative and quantitative methods and involves an element of the creative imagination of speculation. It aims to update the intersections of forces, trends, contradictions and tensions and offers an opportunity to clarify the underlying values (Lange and Martinand, 2010).

The contribution of the sciences to SD must therefore be considered in terms of the construction of a reality and the development of options they allow. But they alone cannot meet the 
requirement of ESD. Sciences and humanities and social sciences are together at the heart of sustainability issues: it is indeed a question of the contribution to the reduction of vulnerabilities, not just of the understandability of hazards, dangerous conditions and causes involved. On one hand, without this progression to action, pupils are likely to lapse into mainstream inhibition. On the other hand, the customary division of ESD issues into subjects and disciplines seems increasingly untenable.

\section{Proposals}

The full results and analysis thus lead us to distinguish three possible methods in ESD: 'nondisciplinary' educational actions of participation in SD, the contribution of scientific disciplines, and complex investigations of the issues at stake. If their connection is not obvious, these three methods are for all that necessary to fulfil the missions developed, work on the scalar dimensions of SD systematically, delineate and understand the issues at stake, develop solutions collectively through the determination of the mechanisms for action, providing the opportunity for education to participate in reducing the vulnerabilities of our societies and to prepare pupils for their role as social actors.

We propose a consideration of these three methods in successive moments, mobilising scientific models and concepts, prospective scenario approaches and collective actions. This approach corresponds for science education to Rogers' 'Vision II'. But we add to it by highlighting the ability to act on the world that science and technology, combined with the rhetorical requirement of ethical debate, give us. As Fourez (1994) argues:

"Focusing on situations of trial and negotiation, [this dual requirement] makes it possible to "record new facts" that are not under the technocrats, and to "describe the operations of justification, denunciation or compromise".

The complexity of the issues in education for sustainability implies two strong recommendations: to admit the incompleteness of the disciplines and the risk that they will naturalise SD issues, and to implement a necessary cooperation between the sciences and humanities.

\section{Bibliography}

Bader, B \& Therriault. G. (2008). La démarche de structuration des îlots de rationalité : une approche des QSV soucieuse d'épistémologie des sciences et d'équité en éducation aux sciences, Efficacité de l'approche des Questions Socialement Vives pour l'éducation à l'environnement et à la durabilité. (in Symposium L. Simonneaux \& A. Legardez (Eds) "Efficacité et équité en éducation », Rennes 2008).

Bidou, J.-E. \& Droy, I. (2009). Décrire la construction temporelle des vulnérabilités. (In S. Becerra, A. Peltier (Eds), Risques et environnement: recherches interdisciplinaires sur la vulnérabilité des sociétés, (pp. 155-170), Paris, L’Harmattan)

Bednarz, N., Desgagné, S., Diallo, P. \& Poirier, L. (2001). Approche collaborative de recherche. Une illustration en didactique des mathématiques. (In : P. Jonnaërt et S. Laurin (Eds.), Les didactiques des disciplines. Un débat contemporain. Québec : Presses de l'Université du Québec). Chevassus-au-Louis, B. (2007). L'analyse des risques, l'expert, le décideur et le citoyen. Versailles, Quae.

Christensen, Cl. (2009).'Risk and school science education', Studies in Science Education, 45:2, 
$205-223$.

Deram, A., Hayet, A. \& van Staevel, E. (2006). Evaluation et acceptabilité des risques environnementaux. Rapport final, Etude RECORD n ${ }^{\circ}$ 04-0810/0811/1A.

Descola, Ph. (2011). L'écologie des autres, l'anthropologie et la question de la nature. Versailles : Quae.

Doron, Cl-O. (2009). Le principe de précaution : de l'environnement à la santé. (In D. Lecourt (Eds) La santé face au principe de précaution, (pp. 3-41), Paris : Presse Universitaire de France).

Dupuy, J.-P. (2002). Pour un catastrophisme éclairé, quand l'impossible est certain, Paris, Seuil, points.

Faucheux, S. \& Nicolaï, I. (2005). Environnement et société : de l'évaluation du risque à son acceptation. Sociétal, 50, 26-32.

Fourez, G. (1997). Qu'entendre par « Îlot de rationalité »? Et par « Îlot interdisciplinaire de rationalité »? Aster, 25, 217-225.

Fourez, G. (1994). Constructivisme et justification éthique. Revue des sciences de l'éducation, vol. 20, n 1, 157-174 http://id.erudit.org/iderudit/031705ar

Godard, O. (2001). Le développement durable et la recherche scientifique ou la difficile conciliation des logiques de l'action et de la connaissance. (In M. Jollivet (Eds) Le développement durable, de l'utopie au concept. (pp. 61-82), Eds Elsevier SAS).

Jenkins, E. W. (2009). Reforming school science education: a commentary on selected reports and policy documents. Studies in science education, vol. 45, $\mathrm{n}^{\circ} 1,65-92$.

Jollivet, M. (2009). Eléments de théorie pour une recherche interdisciplinaire sur les interfaces natures/sociétés. (In D. Hervé et F. Laloë (ed.) Modélisation de l'environnement : entre natures et sociétés. (pp. 9-19). Editions Quae.).

Lange, J.-M. (2005). Rencontre entre deux disciplines scolaires, biologie et mathématiques : première approche des enjeux didactiques de la formation des enseignants de biologie. Revue Canadienne de l'Enseignement des Sciences, des Mathématiques et de la Technologie. Vol. 5, $\mathrm{n}^{\circ} 4,485-502$.

Lange, J-M. \& Martinand, J-L. (2010). Education au développement durable et éducation scientifique: Repères pour un curriculum. (In A. Hasni \& J. Lebeaume (dir) «Enjeux contemporains de l'éducation scientifique et technique », Les Presses de l'Université d'Ottawa, Canada.).

Lange, J.-M. \& Victor, P. (2008). «Elaboration et mise à l'épreuve d'un cadre théorique pertinent permettant l'analyse et le questionnement de l'Education au Développement Durable : vers l'identification d'indicateurs ». Rapport de recherche final à l'action INRP 2005-2008, INRP.

Lange J.-M. \& Victor P. (2006). Didactique curriculaire et «éducation à .... la santé, l'environnement et au développement durable »: quelles questions, quels repères ? Didaskalia, $28,85-100$.

Magnan, A. (2009). La vulnérabilité des territoires littoraux au changement climatique : mise au point conceptuelle et facteurs d'influences. Analyse, IDDRI, 1, 3-27.

Martinand J.-L., (2002). Apprendre à modéliser. (in R. Toussaint (Eds) Changement conceptuel et apprentissage des sciences. Recherches et pratiques. (pp 47-68). Outremont (Québec) : Les éditions logiques.).

Mermet, L. (dir.), (2003). Prospectives pour l'environnement : quelles recherches ? Quelles ressources ? Quelles méthodes ? Paris : La Documentation Française.

Orange Ravachol, D. (2007). Des mises en histoire aux savoirs scientifiques : le cas de lycéens confrontés à quelques problèmes de tectonique des plaques. ASTER, 44, 41-68. 
Roberts, D. (2007). Scientific literacy/science literacy. (In S. Abell \& N. Lederman (Eds.) International handbook of research on science education, (pp. 729-780). Mahwah, NJ:Lawrence Erlbaum.).

Wisner, B., Blaikie, P. Cannon, T.; Davis, I. (2003). At risk, Natural hazards, people's vulnerability and diseaster. London : Routledge.

Weber, M. (1959). Le savant et le politique, Paris, Plon. 1959, $1^{\text {re }}$ édition : 1919. 


\section{Appendix: individual analysis grid}

\begin{tabular}{|c|c|}
\hline Pupil & Interview Tx \\
\hline \multicolumn{2}{|l|}{ Total number of words } \\
\hline \multicolumn{2}{|l|}{ Number of answers } \\
\hline $\begin{array}{l}\text { Average number of words } \\
\text { per answer }\end{array}$ & $\begin{array}{l}\text { The relationship between the total number of words and the number of answers varies with the complexity of } \\
\text { speech }\end{array}$ \\
\hline Answers without verb & \multirow{2}{*}{$\begin{array}{l}\text { The number of answers without verbs and complex answers is related to the ownership of the issues and the } \\
\text { complexity of thinking }\end{array}$} \\
\hline Complex answers & \\
\hline $\begin{array}{l}\text { Complexity indicators } \\
\text { If } \\
\text { Because } \\
\text { While } \\
\text { How }\end{array}$ & $\begin{array}{l}\text { Taken from the work of Boisseau, these help to validate the previous parameters. However, in terms of } \\
\text { structure, oral speech is relatively poor at these ages. These will therefore have to be refined. We retain here } \\
\text { the indicators of reasoning. }\end{array}$ \\
\hline $\begin{array}{l}\text { Uni- or multi-dimensional } \\
\text { thinking }\end{array}$ & $\begin{array}{l}\text { Speech referenced in several dimensions of rationality indicates the complexity of thinking, the ownership } \\
\text { and the state of conceptualisation of the issues at stake. }\end{array}$ \\
\hline $\begin{array}{l}\text { Belief in the role of scientists } \\
\text { 1. information } \\
\text { 2. solution } \\
\text { 3. raising the problem }\end{array}$ & $\begin{array}{l}\text { This belief is crucial for a citizen action: it leads either to passivity (waiting for solutions) or to action (raising } \\
\text { the problem). }\end{array}$ \\
\hline $\begin{array}{l}\text { Number of } \\
\mathrm{Je} \text { ('I') } \\
\text { On (= 'we'), nous ('we') } \\
\text { On (= generic) } \\
\text { Ils ('they'; = others) }\end{array}$ & $\begin{array}{l}\text { An increase in je ('I') or on/nous 'we' relative to an impersonal discourse indicates an ownership of the key } \\
\text { questions in SD. } \\
\text { Ils ('they'), the others, indicates a certain passivity. }\end{array}$ \\
\hline Relationship to others & $\begin{array}{l}\text { Determinant of citizenship: 'I alone can do nothing' may prove to be an obstacle (social obstacle), 'I with } \\
\text { others' is the condition for possible active citizenship }\end{array}$ \\
\hline $\begin{array}{l}\text { School/outside school } \\
\text { connections: - no } \\
\text { - Interconnected }\end{array}$ & $\begin{array}{l}\text { A pupil who spontaniously makes connections between what is done at school and what he does, sees or } \\
\text { hears in his personal life (family, media) has a favorable disposition towards ESD }\end{array}$ \\
\hline $\begin{array}{l}\text { Tone of speech/examples } \\
1-\quad \text { Superficial or } \\
\text { conventional } \\
\text { 2- awareness } \\
\text { 3(a)- argued awareness } \\
\text { 3(b)- desire for action } \\
\text { 4- argued desire for action }\end{array}$ & $\begin{array}{l}\text { Ranking reflects ownership: } \\
\text { Generic compound terms (e.g.: pollution, ozone layer) } \\
\text { Expressed in speech by phrases such as 'I realise that...' } \\
\text { Ditto but expressed through an argument } \\
\text { Willingness to act expressed by phrases such as 'have to', 'I'll do this or that' } \\
\text { Ditto but expressed through an argument }\end{array}$ \\
\hline $\begin{array}{l}\text { Issues at stake in SD } \\
1 \text { - indifferent, } \\
2 \text { - deferred } \\
3 \text { - current }\end{array}$ & $\begin{array}{l}\text { The pupil understands, or not, the interest of addressing SD at school and the necessity to act now. } \\
\text { He supports this education project }\end{array}$ \\
\hline $\begin{array}{l}\text { Attachment to the method } \\
\text { implemented }\end{array}$ & $\begin{array}{l}\text { Pupils are in a 'tourist' or 'utilitarian' relationship, or in a 'dynamic of personal development' (Caillot, 1999). } \\
\text { The pupil supports the non-customary methods implemented (debates, concrete actions, questionning, etc. ) } \\
\text { or is awaiting more usual school work (class work through transference, lessons to learn, exercices, } \\
\text { assessment, etc.) }\end{array}$ \\
\hline $\begin{array}{l}\text { Relationship to learning: } \\
\text { 1. learning for himself } \\
\text { 2. learning involved in the } \\
\text { world }\end{array}$ & $\begin{array}{l}\text { By this the pupil expresses his attachment to cumulative learning and reifies or instead to a learning to } \\
\text { understand and act in the world. }\end{array}$ \\
\hline Recurrent lexical field & General tone of speech represented by recurrent formulas \\
\hline $\begin{array}{l}\text { Summary } \\
\text { Possible obstacle }\end{array}$ & fatalism, epistemic fatalism, supporting \\
\hline
\end{tabular}

